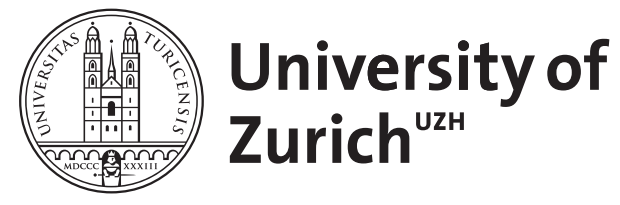

Zurich Open Repository and Archive

University of Zurich

University Library

Strickhofstrasse 39

CH-8057 Zurich

www.zora.uzh.ch

Year: 2014

Access to evidence and presumptions: communicating vessels in procedural law

Heinemann, Andreas

DOI: https://doi.org/10.1007/978-3-662-43975-3_10

Posted at the Zurich Open Repository and Archive, University of Zurich ZORA URL: https://doi.org/10.5167/uzh-102785

Book Section

Originally published at:

Heinemann, Andreas (2014). Access to evidence and presumptions: communicating vessels in procedural law. In: Hüschelrath, Kai; et al. Public and Private Enforcement of Competition Law in Europe: Legal and Economic Perspectives. Heidelberg: Physica-Verlag GmbH und Co., 167-191.

DOI: https://doi.org/10.1007/978-3-662-43975-3_10 


\section{Access to Evidence and Presumptions - Communicating Vessels in Procedural Law}

Andreas Heinemann

\section{General Context}

In the discussion on the European Commission's White Paper on Damages Actions, ${ }^{1}$ the proposals on the disclosure of evidence have attracted great attention and have met with approval by some observers and with rejection by others. The critics point to the risk of introducing a US-style litigation culture in Europe. What is less noticed in this discussion is the fact that some continental legal orders have found another way to fix the problem of evidence: special presumptions are used. In this contribution, the relationship between disclosure obligations and presumptions will be scrutinized. We will see that the success of presumptions is not necessarily due to their substantial persuasiveness but to their role of filling in the continental gaps in the field of disclosure. The advantages and disadvantages of both instruments and their economic rationale shall be discussed.

\section{$2 \quad$ Burden of Proof}

\subsection{Burden of Production, Burden of Persuasion, Burden of Proof}

The starting point is the difference between questions of law and questions of fact. Public authorities have to find their own interpretation of the law (iura novit curia). As regards facts, a distinction has to be made between the burden of production, the burden of persuasion and the burden of proof. The burden of production concerns the question of who has to bring forward evidence for a certain fact. In private law, under the adversary system, facts and evidence have to be introduced by the parties whereas under the inquisitorial system (in administrative and crimi-

1 European Commission, 'White Paper on Damages Actions for Breach of the EC Antitrust Rules', COM(2008) 165 final, 2 April 2008. 
nal law) the public authority or the court has to investigate the facts, including those in favour of the accused party. This does not exclude duties of the parties to cooperate, which often are imposed in administrative procedure.

The burden of persuasion relates to the standard of proof, i.e. the degree of certainty an authority or court has to have with respect to the facts. Common law prefers objective criteria: In private law, preponderance of the evidence has to be found, in criminal law, the existence of the fact must be beyond a reasonable doubt. By contrast, continental systems rely on the inner conviction of judges (and civil servants). The court must not have serious doubts with respect to the existence of a certain fact. Absolute certainty is not required. The degree of certainty in administrative and criminal law has to be higher than in private law. ${ }^{2}$ In all systems, the appreciation of evidence is based on free evaluation. Formal rules of evidence have become very rare. ${ }^{3}$

Finally, the burden of proof (in the narrow, material sense of the word) indicates the one to bear the consequences if a certain fact cannot be proven (situation of non liquet). In private law, according to a generally accepted rule, doubts go against the party claiming rights from the fact in question. ${ }^{4}$ In administrative law, doubts go against the public authorities if the statute does not otherwise provide. In criminal law, the presumption of innocence has to be respected. ${ }^{5}$ Cooperation duties of the parties are admissible if they do not violate the principle of nemo tenetur se ipsum accusare.

\subsection{An Example: The Cartel Interdiction}

These principles may be applied to the prohibition of restrictive agreements in art. 101 TFEU. From a private law perspective, the application of the general rules on the burden of proof would mean that the party that bases its rights on a violation of competition law has to prove the conditions of Art. 101 (1) TFEU, whereas

2 See rule 21.2 of the American Law Institute \& Unidroit, Principles of Transnational Civil Procedure (available at www.unidroit.org/english/principles/civilprocedure/ main.htm): 'Facts are considered proven when the court is reasonably convinced of their truth.' J. P. Westhoff, Der Zugang zu Beweismitteln bei Schadensersatzklagen im Kartellrecht - Eine rechtsvergleichende Untersuchung (Nomos 2010), p. 215 n. 1084 interprets this rule as a compromise between the subjective approach on the continent and the objective standard in common law.

3 For an in-depth analysis of the European Courts' approach including a comparative perspective on the law of the EU Member States, see E. Gippini-Fourier, 'The Elusive Standard of Proof in EU Competition Cases’, 33 World Competition (2010), 187.

4 This principle seems so self-evident that many legal orders refrain from stating an express rule. For an exception see art. 8 of the Swiss Civil Code: 'Unless the law provides otherwise, the burden of proving the existence of an alleged fact shall rest on the person who derives rights from that fact.' See also rule 21.1 of the ALI \& Unidroit Principles (supra note 2): 'Ordinarily, each party has the burden to prove all the material facts that are the basis of that party's case.'

$5 \quad$ See infra 5.2 . 
the other party has to prove the conditions for the efficiency defence in Art. 101 (3) TFEU. ${ }^{6}$ Therefore, for the purpose of private law, the rule in Art. 2 Regulation $1 / 2003^{7}$ has a purely declaratory character.

This is different in public law. Even if it is important to underline that rules on the burden of proof do not affect the duty of the authorities to investigate the facts, ${ }^{8}$ they determine the outcome of the procedure in case of non liquet. The alleged infringer bears the risk that the investigation will not bring out sufficient facts for the efficiency defence. In the language of the error cost approach, the danger of false positives increases. ${ }^{9}$ Moreover, in the field of criminal law, shifting the burden of proof onto the accused party collides with the presumption of innocence. For these reasons, there has been intense discussion on the question whether and, if so, to what extent the transfer of the burden of proof should apply in administrative and criminal law. Art. 2 Regulation 1/2003 apparently strives to apply the principle in public law, too. We will come back to this problem later. ${ }^{10}$ At this

6 The Guidelines on Vertical Restraints (European Commission, OJ 2010, C 130/1, n. 47) go one step further: 'Where such a hard-core restriction is included in an agreement, that agreement is presumed to fall within Article 101(1).' This presumption is not very clear. Although the existence of a hard-core restriction may lead to the presumption of a restriction of competition, it is not relevant for the question if the parties are undertakings or if there is an effect on trade between Member States.

See also Recital 5 s. 2 and 3 of Regulation 1/2003: 'It should be for the party or the authority alleging an infringement of Article 81(1) and Article 82 of the Treaty to prove the existence thereof to the required legal standard. It should be for the undertaking or association of undertakings invoking the benefit of a defence against a finding of an infringement to demonstrate to the required legal standard that the conditions for applying such defence are satisfied.'

$8 \quad$ See Recital 5 s. 4 of Regulation 1/2003: 'This Regulation [does not affect the] obligations of competition authorities and courts of the Member States to ascertain the relevant facts of a case, provided that such [...] obligations are compatible with general principles of Community law.'

9 This concept, developed by Frank H. Easterbrook, 'The Limits of Antitrust', 63 Texas Law Review (1984), is that error costs of false positives (type 1 errors) and false negatives (type 2 errors) have to be weighed. If the costs of type 1 errors are higher than of type 2 errors, the conduct in question is to be allowed. The error cost approach is problematic particularly when the long-term effects on innovation are unclear, but possibly high. In these cases, the error cost approach will often advocate against the application of competition law although intervention may be particularly important in order to safeguard a competitive structure in the long run. See the critique of J. Drexl, 'Is There a 'More Economic Approach' to Intellectual Property and Competition Law?', in J. Drexl (ed.), Research Handbook on Intellectual Property and Competition Law (Edward Elgar Publishing 2008), p. 27, 40 et seq. See also J. Fingleton and A. Nikpay, 'Stimulating or Chilling Competition', 2008 (available at www.oft.gov.uk/news-and-updates/speeches/2008/0808), who warn against the tendency of the error cost approach to underestimate the chilling effect of underintervention. 
point, it is sufficient to mention that EU law does not contain special rules on the standard of proof. According to Recital 5 of Regulation 1/2003, national rules on the standard of proof are not affected.

\subsection{Specific Lack of Evidence in Private Competition Law?}

According to a widespread, but not undisputed opinion, there are specific information asymmetries in private competition law. ${ }^{11}$ They are due to the factual and economic complexity of competition law cases, e.g. the existence of secret practices and the difficulties in the context of market definition, the determination of a dominant position and the cost structure (relevant for the proof of predatory pricing or price abuse). While these points concern the competition law infringement, problems in providing evidence also arise when establishing the loss, the causation between infringement and loss and the requirement of fault if the national rule does not provide for strict liability. On the other hand, certain competitive parameters are quite visible, as for example restrictive terms in distribution agreements, boycott, refusal to deal and refusal to licence as well as the level of selling prices. ${ }^{12}$ As regards the quantification of damages, most European countries provide for flexibility. If through no responsibility of the aggrieved party the precise calculation presents difficulties, then the courts often have the discretion to estimate the extent of losses incurred..$^{13}$

In spite of these qualifications, then, the search for evidence in private competition law cases often poses difficulties. This conclusion does not imply that there are no other fields of law in which difficulties of comparable degree exist (as for example product or environmental liability). But the existence of other problematic issues does not affect the necessity to react to the problems in competition law. The question has to be answered if special rules for competition cases ought to be adopted or if a 'horizontal' approach (covering all fields of law showing comparable difficulties) ought to be preferred. In our view, problems in private competition law are so huge that reforms should start here if the adoption of general rules

11 For a definition, see European Commission, 'Commission Staff Working Paper Annex to the Green Paper on Damages Actions for Breach of the EC Antitrust Rules', SEC(2005) 1732, 19.12.2005, para. 81: 'Information asymmetry exists when one party (usually the defendant) has in its control or has access to more evidence relating to a given claim than the (potential) claimant.'

12 A. Heinemann, 'Interferenzen zwischen öffentlichem Recht und Privatrecht in der Wettbewerbspolitik', in Epiney, Haag, \& Heinemann (eds.), Challenging Boundaries - Essays in Honor of Roland Bieber (Nomos 2007), 681, at p. 695.

13 See Communication from the Commission on Quantifying Harm in Actions for Damages Based on Breaches of Article 101 or 102 of the Treaty on the Functioning of the European Union, OJ 2013 C 167/19, and the accompanying Practical Guide, Commission Staff Working Document $\operatorname{SWD(2013)} 205$ of 11.6.2013, available at http://ec.europa.eu/competition/antitrust/actionsdamages/quantification_guide_en.pdf. 
would delay the reform to some day in the indefinite future. ${ }^{14}$ The example of intellectual property shows that specific problems in a certain legal field constitute a sufficient reason to adopt procedural rules going beyond the general standards. ${ }^{15}$ The initiative of the European Commission to address the problem of scattered damages by introducing collective redress at least for the fields of competition and consumer protection law will serve as an indicator for the chances of success of a horizontal approach. ${ }^{16}$

\section{Coping with Problems of Proof}

\subsection{Options}

There are a number of ways of solving or at least alleviating the problem of proof. Here we find marked differences between common law and the continent. ${ }^{17}$ In common law countries, comprehensive duties of discovery alleviate the burden of proof considerably. ${ }^{18}$ In civil law countries, by contrast, the claimant has to prepare his case carefully. If he realizes that he will not be able to produce comprehensive evidence, it is not advisable for him to go to court. In order to solve the problems - particularly pressing in civil law countries - several options exist:

1. Transition to an inquisitorial system in private competition law

2. Active role of the competition authority in civil procedure

3. Use of administrative decisions in follow on actions

4. Right to information (in substantive law)

14 In this sense, see C. Kersting, 'Perspektiven der privaten Rechtsdurchsetzung im Kartellrecht', Zeitschrift für Wettbewerbsrecht 2008, 252, p. 270; J. P. Westhoff (supra n. 2), p. 181 et seq. For an opposing view, see J.-S. Ritter, 'Private Durchsetzung des Kartellrechts', Wirtschaft und Wettbewerb 2008, 762 (pp. 768-769).

15 Under Article 6 and 7 of the Enforcement Directive (Directive 2004/48/EC of the European Parliament and of the Council of 29 April 2004 on the enforcement of intellectual property rights, OJ 2004 L 195/16) EU Member States have to provide for special disclosure mechanisms following the principle of fact pleading.

16 See Commission Recommendation on Common Principles for Injunctive and Compensatory Collective Redress Mechanisms in the Member States Concerning Violations of Rights Granted under Union Law of 11.6.2013, OJ L 201/60.

17 D. Woods, A. Sinclair and D. Ashton, 'Private Enforcement of Community Competition Law: Modernisation and the Road Ahead', 2 CPN (2004), 31, p 34.

18 For this reason, it may be attractive to take legal action in British courts. See F. W. Bulst, 'The Provimi Decision of the High Court: Beginnings of Private Antitrust Litigation in Europe', European Business Organization Law Review 2003, 623; and id., 'Internationale Zuständigkeit, anwendbares Recht und Schadensberechnung im Kartelldeliktsrecht', Europäisches Wirtschafts- und Steuerrecht 2004, 403, p.404. 
5. Easing of the standard of proof: plausibility instead of full proof?

6. Presumptions

7. Access to evidence in possession of the other or a third party (procedural law)

Option (1) is the most radical one. The principle of administrative procedure would be applied to civil procedure as well (as it is already the case in many countries e.g. in certain areas of family law). ${ }^{19}$ Option (2) would be similar. However, here it is not the court, but the competition authority that actively investigates the relevant facts in a civil procedure. Already today, competition authorities have the possibility of acting as amicus curiae in private competition cases. Art. 15 Regulation 1/2003 provides for a close cooperation of national courts with the European Commission, which applies to private enforcement, too. ${ }^{20}$ Option (3) establishes an authoritative effect of administrative decisions for civil procedure: civil courts are bound by final decisions of the competition authority. Option (4) strives to solve the problems in substantive law: rights to information against infringers are to be strengthened. These rights may be enforced, or the failure to perform may entail negative conclusions against the disrespectful party. Option (5) would revolutionize the requirements for the standard of proof. The plaintiff would not be obliged any longer to adduce full proof, but it would be sufficient for him to render his claim plausible. Less far reaching is the plea for more presumptions (Option (6)) concerning selected elements of competition law violations. Finally, option (7) would strengthen the competence of the court to impose disclosure of evidence in possession of the other party or of third parties.

\subsection{Discussion}

In our view, reforms in the field of evidence are overdue. Evidentiary difficulties are particularly strong in the field of private competition law enforcement. As the result is an undue preference of the respondent, it is appropriate to modify the rules on evidence to the advantage of the plaintiff. If private enforcement is to be strengthened, there have to be improvements in this field. The goal is to reestablish an adequate balance between the interests of both sides.

19 See R. Zäch and R. A. Heizmann, 'Durchsetzung des Wettbewerbsrechts durch Private', in Essays in Honor of Stanislaw Soltysinski (Poznan 2005), 1059, p. 1066; R. Zäch, Schweizerisches Kartellrecht (Stämpfli, $2^{\text {nd }}$ ed. 2005), para. 850.

20 See Commission Notice on the co-operation between the Commission and the courts of the EU Member States in the application of articles 81 and 82 EC, OJ $2004 \mathrm{C}$ 101/54. As Art. 15 Regulation 1/2003 only establishes a minimum level, national law may confer wider powers on competition authorities of the Member States. See for example Art. 90 (2) of the German Act against Restraints of Competition (ARC), which gives the Federal Cartel Office the right 'to submit written statements to the court, to point out facts and evidence, to attend hearings, to present arguments there, and to address questions to parties, witnesses and experts.' Pointing out evidence does not confer a formal right to take certain evidence; rather, it allows the authority to play an active role. 


\subsubsection{Inquisitorial System}

For this reason, no use should be made of option (1). The adoption of the inquisitorial system in private law would confer the same tasks to the courts that competition authorities have in administrative procedures. It is highly doubtful if courts without the organizational substructure competition authorities have - would be able to cope with such a far-reaching task.

\subsubsection{Amicus curiae Function of Competition Authorities}

The amicus curiae function of competition authorities in private enforcement should be expanded. The European Commission's Report on the Functioning of Regulation $1 / 2003^{21}$ has revealed that national courts tend to hesitate before asking questions to the European Commission. Therefore, competition authorities should be given the right to intervene in private procedures on their own initiative, since this is already the case in some countries. On the other hand, for the sake of the independence of competition authorities and with respect to their limited funding, this should not be understood in the sense that competition authorities would be obliged to make a full-fledged investigation. Rather, it is desirable that they can give input and indicate evidence which might be important to consider. Therefore, it is not about introducing an inquisitorial system through the backdoor of a competition authority's intervention. It is about strengthening the amicus curiae function of these authorities.

\subsubsection{Binding Effect of Administrative Decisions}

In some countries, courts are formally bound by (final) decisions of competition authorities. In the EU, Art. 16 Regulation 1/2003 provides for a binding effect of the European Commission's decisions for national courts. In the European Union, this principle could be extended to the decisions of national competition authorities in the EU Member States, as it is already the case in German law. ${ }^{22}$ The argument in favour of a binding effect is the high authority of a decision that has been taken on the basis of a comprehensive investigation and that was open to judicial challenge. But this should not raise too many expectations: even in countries without a formal binding effect, administrative decisions will have a high level of persuasive authority.

\footnotetext{
21 European Commission, 'Communication from the Commission to the European Parliament and the Council - Report on the Functioning of Regulation 1/2003', $\operatorname{COM}(2009) 206$ final, 29 April 2009. 


\subsubsection{Right to Information}

Already today, in many legal orders rights to information in substantive law exist. ${ }^{23}$ They may be useful in certain contexts. But compared with the procedural duties of disclosure they appear laborious. It is more effective if the court orders disclosure of evidence directly. Therefore, procedural duties of disclosure will be looked at more closely later.

\subsubsection{Easing of the Standard of Proof}

Option (5) would transfer the pleading standard in the US (which is plausibility ${ }^{24}$ ) to standard of proof. It would be up to the defendant to rebut the plaintiff's allegations once they have reached the level of plausibility. A general presumption of a competition law violation in case of plausible allegations would be introduced. This does not seem adequate, however. The standard of proof determines the outcome of a civil suit. If it is too low, the risk of wrong judgments increases considerably. This does not seem compatible with fundamental principles of private law. It is with good reason that the European Commission rejected proposals going in this direction. ${ }^{25}$

\subsubsection{Access to Evidence and Presumptions}

Hence, the discussion on alleviations should focus on the rules governing access to evidence in civil procedure and on specific presumptions as a means to shift the burden of proof. Both concepts stand in close relationship to each other. Before analyzing the justification of presumptions, proposals on how to create better evidence access will be discussed.

23 With respect to German law, see the analysis by R. Wilhelmi, 'Zugang zu Beweismitteln und Auskunftsanspruch - Die Regelungen des deutschen Rechts und des Weißbuchs im Vergleich', in Möschel and Bien (eds.), Kartellrechtsdurchsetzung durch private Schadenersatzklagen? (Nomos 2010), 99, p. 104 et seq.

24 See US Supreme Court in the Bell Atlantic Corp. v. Twombly case, 550 U.S. 544 (2007). The Supreme Court underlined that for fulfilling the plausibility standard it is not sufficient that the claim - on the basis of the facts mentioned - is merely conceivable: 'Asking for plausible grounds does not impose a probability requirement at the pleading stage; it simply calls for enough fact to raise a reasonable expectation that discovery will reveal evidence of illegal agreement.'

25 European Commission, 'Commission Staff Working Paper accompanying the White Paper on Damages Actions for Breach of the EC Antitrust Rules', SEC(2008) 404, para. 91. 


\section{$4 \quad$ Access to Evidence}

In public enforcement, access to evidence is not a major problem. Under the inquisitorial system, competition authorities have on hand a variety of instruments, e.g. the enforceable right to request for information, the power to take statements and the conduct of inspections in undertakings or other premises. Leniency programmes create incentives for infringers to reveal secret practices. Problems of access to evidence have recently been discussed as far as the access of accused parties is concerned. Inspired by the US model, the question is raised if crossexamining of witnesses should be introduced into administrative and court procedure. $^{26}$

\subsection{The Proposal of the European Commission}

In the White Paper, based on the assumption of a structural information asymmetry, the European Commission has proposed a system of fact pleading as opposed to notice pleading known from US law. ${ }^{27}$ A minimum level of disclosure is considered desirable that is linked to detailed conditions. The claimant has to present all facts and means of evidence reasonably available. They have to show plausible grounds for a harm caused by the defendant. The claimant must be unable to produce the requested evidence. Precise categories of evidence have to be specified. ${ }^{28}$ If the requested evidence is relevant, necessary and proportionate, the court will order the defendant (or third parties) to submit this evidence. An exception applies in the case of corporate statements by leniency applicants. ${ }^{29}$

26 F. Castillo de la Torre, 'Evidence, Proof and Judicial Review in Cartel Cases', 32 World Competition (2009), 505, p. 534 et seq. with further references. For the subject of cross examination in the context of civil procedure, see R. Stürner, 'Duties of Disclosure and Burden of Proof in the Private Enforcement of European Competition Law', in J. Basedow (ed.), Private Enforcement of EC Competition Law (Kluwer Law International 2007), 163, at p. 180-181.

27 For the difference between fact pleading and notice pleading, see e.g. R. Stürner (supra note 26), p. 170-171.

28 The European Commission gives the following examples (Commission Staff Working Paper, supra note 25, para. 106): Documents about price discussions between cartelists for a clearly described product, period and territory to the extent that they may concern the claimant; disclosure - for a specified product, period and territory - of facts to enable the claimant to determine what the pricing structure on the market would have been in the absence of the cartel (including details of prices prior to the cartel and of price discussions during the life of the cartel). 


\subsection{Discussion}

Continental systems oblige the claimant to produce all the evidence relevant for his claim. In specific situations, rights of information or procedural rules of disclosure exist but they are of limited scope. Although these alleviations have been subsequently extended, ${ }^{30}$ they are not of great help in the field of secret anticompetitive behaviour. This contributes to the phenomenon of private underenforcement in the field of stand-alone actions. ${ }^{31}$ By contrast, US-style notice pleading creates the danger of fishing expeditions, high procedural costs and the risk of blackmail settlements. ${ }^{32}$ Therefore, a middle ground has to be found. ${ }^{33}$

A useful text identifying a way between extremes are the Principles of Transnational Civil Procedure adopted by the American Law Institute and Unidroit. ${ }^{34}$ Rule 16 states the principle that each party should have access to all relevant, nonprivileged and reasonably identified evidence in the possession or control of another party or, if necessary and on just terms, of a non-party. It is not a basis of objection to such disclosure that the evidence may be adverse to the party or person making the disclosure.' Even if the Principles appear as a compromise between different systems of disclosure, it has to be underlined that they start from the idea of fact pleading. Hence, they do not pave the way for fishing expeditions, but they invite states to leave behind rules that inadequately favour alleged infringers. ${ }^{35}$ The English example demonstrates that balanced rules on disclosure may solve the difficulties of producing evidence without causing excessive litigation. The proposal of the European Commission in the White Paper is perfectly in line with these specifications. It may be added that an expansion of disclosure rules does not violate unwritten rules of procedural law. The often-quoted principle of nemo ten-

30 See R. Stürner, 'The Principles of Transnational Civil Procedure - An Introduction to Their Basic Conceptions', 69 Rabels Zeitschrift für ausländisches und internationales Privatrecht (2005), 201, p. 233 et seq.

31 In follow-on suits, problems of adducing evidence are mitigated by the information supplied by competition authority decisions, especially if they have a binding effect. See W.-H. Roth, 'Private Enforcement of European Competition Law - Recommendations Flowing From the German Experience', in J. Basedow (supra n. 26), 61, p. $77-78$.

32 See P. Beschorner and K. Hüschelrath, 'Ökonomische Aspekte der privaten Durchsetzung des Kartellrechts', in Möschel and Bien (supra note 23), 9, p. 12. These risks are not removed, but only reduced by the fact that the US Supreme Court has tightened the requirement of plausibility, see supra note 24.

33 For a comparative perspective, see D. Gerber, 'Extraterritorial Discovery and the Conflict of Procedural Systems: Germany and the United States', 34 American Journal of Comparative Law (1986), 745.

$34 \quad$ Supra note 2.

35 See the assessment of R. Stürner (supra note 30), p. 237: 'In this way the Principles reach a reasonable solution appropriate to avoid the excesses of both traditional legal systems; namely, the tendency of the American procedure towards overbroad discovery on the one hand, and the danger of a too early termination of fact finding in the continental tradition on the other.' 
etur edere contra se is not compatible with modern developments in private procedure. ${ }^{36}$ With respect to EU law, the European Court of Justice has decided that nemo tenetur does not apply in civil proceedings, which cannot lead to the imposition of a penalty. ${ }^{37}$

In the area of competition law, specific reasons may be added. The more economic approach taken in European competition law and partial spilling over into the legal orders of the EU Member States has replaced the form-based by an effects-based analysis. Under the new approach, the importance of the factual basis has increased considerably. ${ }^{38}$ The appreciation of all circumstances of the individual case has taken center stage and creates the tendency to push back general rules. This is not the place to discuss the pros and cons of this development. ${ }^{39}$ For the purpose of private enforcement, this development means that access to evidence has become crucial. The important role of economics only makes sense in a system where access to the factual material is granted. Therefore, the increasing role of economics in competition law should go along with improved access to evidence. Fishing expeditions will not be possible if the necessary precautions are taken, and if access is placed under close judicial control.

\section{$5 \quad$ Presumptions and Other Rules on the Burden of Proof}

\section{$5.1 \quad$ Concept}

A presumption bases the existence of a certain fact or legal situation on the existence of other facts. Rebuttable presumptions are an instrument to shift the burden of proof. Thus, they modify the general rules in this area. For a rebuttal of the pre-

\footnotetext{
$36 \quad$ R. Stürner (supra note 30), p. 235 para. 163.

37 Case C-60/92 Otto/Postbank [1993] ECR, I-5683, para. 21.

38 See the interesting observation of D. Gerber, Global Competition - Law, Markets, and Globalization (Oxford University Press 2010), p. 137 according to which it is not only true that the economic approach requires broad access to facts, but that - conversely - the expansion of discovery rights in US law 'has played a major role in the ascendancy of economics-based analysis' and thus has promoted the change of substantive law in the direction of the economic approach.

39 For an analysis, see for example M. Hellwig, 'Effizienz oder Wettbewerbsfreiheit? Zur normativen Grundlegung der Wettbewerbspolitik', in Engel \& Möschel (eds.), Recht und spontane Ordnung - Festschrift für Ernst-Joachim Mestmäcker zum achtzigsten Geburtstag (Nomos 2006), p. 231 et seq.; Schmidtchen, Albert \& Voigt (eds.), The More Economic Approach to European Competition Law (Mohr Siebeck 2007); R. Zäch and A. Künzler, 'Freedom to Compete or Consumer Welfare: The Goal of Competition Law according to Constitutional Law', in Zäch, Heinemann and Kellerhals (eds.), The Development of Competition Law - Global Perspectives (Edward Elgar Publishing 2010), p. 61 et seq.
} 
sumption, full proof of the contrary has to be provided. It is not sufficient to offer evidence giving reason for doubt. ${ }^{40}$ This is different from prima facie or res ipsa loquitur evidence (evidential presumptions ${ }^{41}$ ), a sort of indirect evidence based on general experience, where rebuttal simply requires the creation of serious doubts. ${ }^{42}$ Conclusive presumptions (praesumptio iuris et de iure) cannot be rebutted. They are in most cases disguised rules of law. ${ }^{43}$

\subsection{Different Effects of Presumptions in Private, Administrative and Criminal Law}

In private law, as we have seen, a presumption shifts the burden of production and the burden of proof onto the other party. Thus, presumptions have full effect in private law. The situation is different in public law (administrative and criminal). In an inquisitorial system, presumptions do not affect the mission of the authorities to investigate the facts. Therefore, presumptions do not in principle affect the burden of production on administrative authorities and the courts. However, presumptions may add a secondary burden of production onto the parties ${ }^{44}$ in addition to general cooperation duties. In administrative law, presumptions determine the outcome if it is not possible to clear a matter up (non liquet).

40 In the German terminology the rebuttal requires a Hauptbeweis, not only a Gegenbeweis. See Art. 292 of the German Code on Civil Procedure; for Swiss law, see A. Staehelin, D. Staehelin and P. Grolimund, Zivilprozessrecht (Schulthess Verlag 2008), p. 258.

41 See the distinction between evidential, substantive and procedural presumptions by D. Bailey, 'Presumptions in EU Competition Law', 31 European Competition Law Review (2010), 362-369.

42 Normally, prima facie situations are identified by the courts. An example for a legal prima facie rule is Art. 20 (4) of the German ARC, which imposes on the other party the task of clarifying circumstances in his field of business if on the basis of specific facts and of general experience there seems to be exclusionary abuse. See R. Stürner (supra note 26), p. 185-186, who criticizes the combination of prima facie evidence and obligations to cooperate and who concludes that it 'is difficult enough to formulate helpful evidentiary rules, and it is more difficult to do so in special fields of law in accordance with the general law of evidence.' For a more favourable view of prima facie assumptions, see W.-H. Roth (supra note 31), p. 77-78.

43 On the historical development of presumptions, see Helmholz \& Sellar (eds.), The Law of Presumptions: Essay in Comparative Legal History (Duncker \& Humblot 2009).

44 See Joined Cases C-204/00 P, C-205/00 P, C-211/00 P, C-213/00 P, C-217/00 P and C-219/00 P Aalborg Portland and Others/Commission [2004] ECR I-123, para. 79: 'Although according to those principles the legal burden of proof is borne either by the Commission or by the undertaking or association concerned, the factual evidence on which a party relies may be of such a kind as to require the other party to provide an explanation or justification, failing which it is permissible to conclude that the burden of proof has been discharged.' 
In criminal law, the legal prerequisites are different. First, it has to be underlined that, for the purpose of the European Convention on Human Rights, competition law has to be qualified as criminal law as far as fines of a certain amount are concerned. ${ }^{45}$ Therefore, the presumption of innocence, laid down in Art. 6 (2) ECHR, applies. ${ }^{46}$ This does not rule out the use of presumptions in criminal law; it only establishes restrictions. According to the European Court of Human Rights, the presumption of innocence 'requires States to confine them [scil. presumptions] within reasonable limits which take into account the importance of what is at stake and maintain the rights of the defence. ${ }^{47}$ As regards the importance at stake, it has to be underlined that the fundamental rights do not apply to all forms of criminal offences with the same intensity. According to the European Court of Human Rights, outside the hard core of criminal law, 'the criminal-head guarantees will not necessarily apply with their full stringency'. ${ }^{48}$ The Court has explicitly mentioned competition law as an example of 'cases not strictly belonging to the traditional categories of the criminal law'. ${ }^{49}$ Therefore, careful use of presumptions may be made in this area. As regards the rights of defence, it is essential that presumptions are rebuttable. Hence, conclusive presumptions are excluded in the field of criminal law. Likewise, it would be incompatible with the rights of defence if a rebuttal of the presumption were impossible for practical reasons (probatio diabolica). In order to strike an appropriate balance, presumptions should be interpreted as mere prima facie rules in the context of criminal law. Thus, not the proof of the contrary would be necessary, only the creation of serious doubt. In the case law of the European Court of Justice, this requirement is fulfilled by the rules on a secondary shift of the burden of proof. ${ }^{50}$

\subsection{The Efficiency Defence}

We have already seen that the burden of proving the conditions for the efficiency defence in Art. 101 (3) TFEU is on the party claiming the benefit of this defence. ${ }^{51}$ In private law, this rule is immediately plausible. By contrast, the application of this rule in public law proceedings has been criticized. ${ }^{52}$ In order to assess this crit-

45 See W. Wils, 'The Increased Level of EU Antitrust Fines, Judicial Review and the ECHR', 33 World Competition (2010), 5, p. 12 et seq.

46 The same is true for the presumption of innocence in EU law. See ECJ, Case C199/92 P Hüls/Commission [1999] ECR I-4287, para. 149-150; and Art. 48 (1) Charter of Fundamental Rights of the European Union.

47 ECtHR, case no. 10519/83 of 7 October 1988 - Salabiaku v. France, no. 28.

48 ECtHR, case no. 73053/01 of 23 November 2006 - Jussila v. Finland, no. 43.

49 Ibid; confirmed by ECtHR, case no. 43509/08 of 27 September 2011 - Menarini Diagnostics $v$. Italy.

$50 \quad$ Supra note 44.

51 Supra 2.1.

52 See for example J. Schütz in Hootz (ed.), Gemeinschaftskommentar (Heymann, $5^{\text {th }}$ ed. 2004), Art. 2 Regulation 1/2003 n. 1 et seq. For Swiss law, see A. Raas, 'Verfehl- 
icism, we have to inquire after the rationale of this rule. An explanation can be found in the legal basis of Art. 2 Regulation 1/2003, which is Art. 103 (2) lit. b TFEU. The rules for the application of Art. 101 (3) TFEU shall take 'into account the need to ensure effective supervision on the one hand, and to simplify administration to the greatest possible extent on the other'. It is certainly in the interest of effective supervision and of simplified administration to attribute the burden of proof for the efficiency defence onto the alleged infringer. At the same time, error costs caused by false positives are increased if the burden of proof in non liquet situations is placed on private parties. In our view, shifting the burden of proof onto private parties is nevertheless justified, as the facts suited for proving the four conditions in Art. 101 (3) TFEU are typically situated in the sphere of the parties to the agreement, making it much easier for them to find and to present these facts in an administrative procedure. According to case law, it is sufficient for the parties to deliver convincing arguments and evidence. If the Commission does not succeed in refuting these arguments and evidence, the enterprise has discharged the burden of proof. ${ }^{53}$ This seems to be an efficient distribution of the burden of proof. The danger of false positives is reduced by the rules on the secondary burden of proof, and social costs will decrease because administrative costs are reduced considerably. ${ }^{54}$

In criminal law, however, different standards apply. There is an intense debate on the question whether, in competition law fining procedures, charging the undertakings with the burden of proof for the efficiency defence is compatible with the presumption of innocence. ${ }^{55}$ As we have already seen, competition law has to

te Beweislastumkehr in Kartellrechtsverfahren - Im Zweifel für die Vertragsfreiheit', sic! 2007, 423.

53 Supra note 44 and Case T-168/01 GlaxoSmithKline Services/Commission [2006] ECR II-2969, para. 235-6; Joined Cases C-501/06 P, C-513/06 P, C-515/06 P and C519/06 P GlaxoSmithKline/Commission, [2009] ECR I-9291, para. 81-88.

54 For an economic analysis of procedural law, see infra 6.

55 For favourable views of the full application of Art. 2 Regulation 1/2003, see Dalheimer in Grabitz \& Hilf (eds.), Das Recht der Europäischen Union, Kommentar (C.H. Beck 2012), nach Art. 83, Art. 2 Regulation 1/2003 para. 12 et seq.; and Lampert, Niejahr, Kübler and Weidenbach, EG-Kartellverordnung - Praxiskommentar (Verlag Recht und Wirtschaft 2004), Art. 2 Regulation 1/2003 para. 82. For a critical view of this kind of allocation, see Bechtold, Brinker, Bosch and Hirsbrunner (eds.), EG-Kartellrecht - Kommentar (C.H. Beck, $2^{\text {nd }}$ ed. 2009), Art. 2 Regulation 1/2003, para. 24; G. Dannecker and J. Biermann, in Immenga \& Mestmäcker (eds.), Wettbewerbsrecht Band 1, EU/Teil 2, Kommentar zum Europäischen Kartellrecht (C.H. Beck, 5th ed. 2012), Vorbemerkungen zu Art. 23 ff. Regulation 1/2003 para. 66; and K. Schmidt in Immenga \& Mestmäcker (eds.), Wettbewerbsrecht Band 1, EU/Teil 2, Kommentar zum Europäischen Kartellrecht (C.H. Beck, 5th ed. 2012), Art. 2 Regulation 1/2003 para. 39. The German delegation submitted a statement on Art. 2 Regulation $1 / 2003$ that was entered into the Council minutes at the time that Regulation 1/2003 was adopted: 'Supplementary in particular to Recital 5 of the Regulation under consideration, the Government of the Federal Republic of Germany reiterates its view that Article 83 of the Treaty does not constitute a sufficient legal basis for intro- 
be qualified as criminal law as far as fines of a certain amount are concerned. ${ }^{56}$ But as pointed out above, the presumption of innocence does not categorically exclude presumptions or a distribution of the burden of proof that disfavours undertakings. It all depends on the 'reasonable limits', i.e. the importance of the offence and the maintenance of the rights of the defence. ${ }^{57}$ In this respect, it has to be stressed that competition law fines are imposed for clear violations, mostly in the field of hard-core restrictions. It is very rare for undertakings to be fined in a situation where the scope of the efficiency defence is in dispute. ${ }^{58}$ For the distribution of the burden of proof provided for in Art. 2 Regulation 1/2003, objective reasons exist. As we have already seen, it is hardly possible to prove the absence of the efficiency defence. The investigation has to be based on the arguments of the parties in question. Of course, as shown in the context of administrative law, it is up to the authority to rebut the factual evidence brought forward by an undertaking. Because of secondary rules of this type, there is no 'automatic reliance' ${ }^{59}$ on the distribution of the burden of proof. The 'reasonable limits' underlined by the European Court on Human Rights are respected.

\subsection{Per se Prohibition and Rule of Reason}

Whereas presumptions refer to single facts or legal terms (e.g. dominance), the distinction between per se prohibition and rule of reason refers to a legal rule in its entirety. If a certain conduct is caught by a per se prohibition, the plaintiff has to prove the elements of the prohibition. If he succeeds, the defendant cannot object since the prohibition in its entirety works as an irrefutable presumption. The most famous example is the per se rule of US Antitrust Law in its classical conception. By contrast, a legal rule modelled according to the rule of reason, provides for a prohibition with exceptions. In the US version, pro- and anti-competitive effects have to be balanced. According to the European approach, prohibitions and exceptions are formulated in a more specific way, which might be called a structured rule of reason. The plaintiff has to prove the elements of the prohibition. The de-

ducing or amending provisions governing criminal law or criminal proceedings. This especially applies with regard to fundamental procedural guarantees in criminal proceedings such as the presumption of innocence of the accused. The Government of the Federal Republic of Germany points out that, in Germany, these procedural guarantees also apply to proceedings equivalent to criminal proceedings such as proceedings on administrative fines, and that they enjoy constitutional status. The Government of the Federal Republic of Germany thus expects that the Regulation under consideration, in particular Article 2, will neither amend nor impair Member States' criminal-law or criminal-proceedings provisions or legal principles applicable to criminal proceedings or proceedings equivalent to criminal proceedings.'

Supra 5.2.

Supra note 47.

K. Schmidt, supra note 55.

See ECtHR, case no. 13191/87 of 25 September 1992 - Pham Hoang v. France, no. 36 . 
fendant may rely on an exception; in this case he has to prove the prerequisites of this exception. For both types of rules, there may be presumptions with respect to certain elements, normally in favour of the plaintiff, but sometimes also in favour of the defendant (e.g. safe harbours). ${ }^{60}$

In US law, the clear distinction between per se prohibitions and rule of reason has been blurred by the quick look or truncated analysis under which hard-core restrictions may be open to justification. ${ }^{61}$ This process goes along with the development of the rule of reason to a 'structured' rule creating (rebuttable) presumptions. In European law, there has never been a per se rule, as the defence in Art. 101 (3) TFEU applies to all restraints, be they hard-core or simple restrictions. ${ }^{62}$ For a long while it has been said that the prerequisites of justification will virtually never be met if there is a hard-core restriction. But under the more economic approach, there is more space for justification even in the hard-core area. ${ }^{63}$

60 An interesting approach to presumptions is to be found in Swiss competition law. According to Art. 5 (3) and (4) of the Swiss Cartel Act (CartA), there are presumptions for an elimination of effective competition in case of certain hard-core restrictions. If there is an elimination of effective competition, the law does not admit the efficiency defence (which is available only if the agreement restricts but does not eliminate competition). Since these presumptions are refutable, the rules in question do not constitute per se prohibitions. See A. Künzler and R. A. Heizmann, 'Art. 5 Abs. 4 des schweizerischen Kartellgesetzes im Lichte der Leegin Entscheidung des U.S. Supreme Court', in Weber, Heinemann \& Vogt (eds.), Methodische und konzeptionelle Grundlagen des Schweizer Kartellrechts im europäischen Kontext (Stämpfli 2009), p. 133 et seq.; R. Zäch and A. Künzler, 'Abschaffung der Vermutung von Art. 5 Abs. 4 des schweizerischen Kartellgesetzes - ein Schildbürgerstreich', in Oertle, Wolf, Breitenstein \& Diem (eds.), M\&A: Recht und Wirtschaft in der Praxis - Liber amicorum für Rudolf Tschäni,(Dike 2010), p. 465 et seq.

61 See L. A. Sullivan and W. S. Grimes, The Law of Antitrust: An Integrated Handbook (Westgroup 2000), p. 167-168.

62 See R. Whish, Competition Law (Oxford University Press, $6^{\text {th }}$ ed. 2009), p. 150: 'In this sense EC law differs from US law, since there are no agreements that are "per se" illegal in the EC system.' For the same reason, the distinction in European competition law between restrictions by object and by effect cannot be put on the same level as the distinction between per se prohibitions and the rule of reason in US antitrust law. See Whish, ibid., p. 118-119.

63 Compare the old Guidelines on Vertical Restraints (European Commission, OJ 2000, C 291/1, para. 46: 'Individual exemption of vertical agreements containing such hardcore restrictions is also unlikely.') with the new one (European Commission, Guidelines on Vertical Restraints, OJ 2010 C 130/1, para. 47: 'However, undertakings may demonstrate pro-competitive effects under Article 101(3) in an individual case.'). 


\section{An Economic Analysis of Disclosure Obligations and Presumptions}

\subsection{Justification of Presumptions}

When should the legislature or the courts provide for presumptions? A starting point may be found in the rationale of per se interdictions in US Antitrust Law. The US Supreme Court has held that 'per se rules of illegality are appropriate only when they relate to conduct that is manifestly anticompetitive. ${ }^{64}$ Certain categories of restraints 'always or almost always tend to restrict competition and decrease output' ${ }^{65}$ and 'lack $[\ldots]$ any redeeming virtue' ${ }^{66}$ These requirements apply to the per se prohibition, i.e. an irrefutable presumption. Which conditions should apply to rebuttable presumptions? With respect to the rule of reason, the US Supreme Court has held in the Leegin case that "courts can, for example, devise rules over time for offering proof, or even presumptions where justified, to make the rule of reason a fair and efficient way to prohibit anticompetitive restraints and to promote pro-competitive ones. ${ }^{67}$ So, the leading principle should be the search for a 'fair and efficient way'. This requires an economic analysis of presumptions and of procedural rules.

Procedural law is an instrument for applying substantive law. The use of the procedural system causes administrative costs (courts, lawyers, fact-finding) and errors in outcome, which distort incentives (error costs). From an economic perspective, the goal of procedural law is to minimize social costs, which are the sum of administrative and error costs. ${ }^{68}$ There is a trade-off between administrative costs and error costs: the bigger the procedural efforts are, the less likely errors are to occur (and vice versa) ${ }^{69}$

64

65

66

67

68

69

Sylvania, 433 U.S. 36 (1977) at 49-50.

Broadcast Music v. Columbia Broadcasting System, 441 U.S. 1 (1979) at 19-20.

Northern Pacific Railroad Co. v. United States, 356 U.S. 1 (1958) at 5.

Leegin Creative Leather Products, Inc. v. PSKS, Inc., 551 U.S. 877 (2007) at 898899.

See R. Cooter and Th. Ulen, Law and Economics et al. (Prentice Hall, $6^{\text {th }}$ ed. 2011), p. 384 et seq.; and R. Posner, Economic Analysis of Law (Wolters Kluwer, $7^{\text {th }}$ ed. 2007), p. 593 et seq.

On a more general level, it could be asked what effect the arrangement of civil procedure has on total welfare or on consumer welfare. The interaction of public and private enforcement would have to be analyzed in this respect, including the impact of private enforcement on leniency programmes. This article starts from the idea that victims of competition law violations should be compensated so that the impact on public enforcement only allows a cautious interference with that goal. In the US, a link between compensation and leniency exists. See US Department of Justice, Corporate Leniency Policy (1993, www.usdoj.gov/atr/public/guidelines/0091.htm), A5 and B6: 'Where possible, the corporation makes restitution to injured parties.' 


\subsection{Economics of Disclosure Obligations}

Disclosure obligations increase administrative costs for the parties because they have to screen the evidence in their possession as to their relevance for the procedure. In many cases, this requires that a large number of documents be produced. There may be disputes on the extent of the duty to submit documents. If business secrets are not protected sufficiently, disclosure may harm the business prospects of the party concerned. As for error costs, disclosure obligations will diminish them since the judgment is given on a broader factual basis. But error costs may also rise because of the risk of discovery blackmail.

Disclosure obligations will reduce social costs if a reduction of error costs outweighs an increase in administrative costs. The increase in administrative costs may be moderated by a careful limitation of disclosure obligations and by an adequate protection of business secrets. This would also reduce the risk of 'discovery blackmail'. It is imaginable to provide for discovery obligations of a different weight depending on whether a competition law violation (more protection of the defendant) or the extent of damages is concerned once such a violation has been established (less protection of the defendant, such as with follow-on suits). For a complete analysis, many other factors would have to be taken into consideration, e.g. the introduction of evidence known from administrative procedures into civil procedures, disclosure obligations of third parties or the possibility of disclosing only towards independent experts.

\subsection{Economics of Presumptions}

Presumptions aim to influence the trade-off between administrative costs and error costs. ${ }^{70}$ They diminish administrative costs, but increase error costs. Irrefutable presumptions reduce administrative costs more than rebuttable presumptions by creating absolute legal certainty (e.g. per se prohibitions or per se legality). At the same time errors of presumption cannot be straightened out. The closer a presumption is to reality, the more likely savings in administrative costs will be higher than the increase in error costs. Hence, presumptions allow social costs to be reduced in situations where it is highly probable that the presumed fact has occurred or that the legal situation is given.

\footnotetext{
70 For an economic analysis of presumptions, see A. Bernardo, E. Talley and I. Welch, 'A Theory of Legal Presumptions', 16 The Journal of Law, Economics, \& Organization (2000), 1. For the purpose of economic analysis, presumptions are qualified here as procedural law. This qualification is made notwithstanding the legal qualification of (some) presumptions as substantive law in many legal orders. For EU competition law, see Case C-8/08 T-Mobile Netherlands [2009] ECR I-4529, para. 44-53.
} 


\section{$7 \quad$ Examples}

Three examples of presumptions shall be analysed as to their economic justification. In part, these presumptions are provided for by the law (or are being proposed to become law); others have been established by the courts.

\subsection{Dominant Position}

\subsubsection{Market Shares}

In several countries, a dominant position is presumed if a firm holds a certain market share. There are presumptions for single dominance and for dominance in oligopolies. If we look only at single dominance, according to German law, 'an undertaking is presumed to be dominant if it has a market share of at least 40 per cent', Art. 18 (4) ARC. In Austria, the presumption of dominance starts from a market share of 30 per cent according to Art. 4 (2) n. 1 of the Austrian Cartel Act. ${ }^{71}$ In EU law, there is no written presumption of dominance but the European Court of Justice has resumed its practice in the AKZO case: 'With regard to market shares the Court has held that very large shares are in themselves, and save in exceptional circumstances, evidence of the existence of a dominant position ... . That is the situation where there is a market share of $50 \% \ldots{ }^{72}$

These presumptions cannot simply be explained by historical remnants of an old-fashioned structuralist approach inspired by the out-dated model of perfect competition. To the contrary, market share presumptions also seem to be attractive for more recent competition laws. In Article 19 of the Chinese Antimonopoly Act of 2007, for example, dominance is presumed starting from a market share of 50 per cent. Apparently, presumptions of dominance based on market shares are attractive for states that have introduced competition law quite recently because it facilitates the application of the new law. ${ }^{73}$ Does this mean that mature competition law nations may renounce on these presumptions since they are more appropriate for an early stage of advancement ${ }^{74}$ In order to answer this question, an economic analysis of presumptions of dominance has to be made.

71 See also R. A. Heizmann, 'Relative Marktmacht, überragende Marktstellung - Eine Analyse nach sechs Jahren Praxis', recht 2010, 172, p. 184 et seq., who proposes that such presumptions be introduced into Swiss law. According to this proposal, the threshold for single dominance would be fixed at $40 \%$ (ibid., at p. 187).

72 Case C-62/86 AKZO/Commission [1991] ECR I-3359, para. 60.

73 For the influence of German law on the Chinese Antimonopoly Act, see D. Gerber (supra, note 38), p. 228 para. 33, p. 233.

74 See OECD, Judicial Enforcement of Competition Law (Paris 1997), p. 13: 'There is a trend away from the use of such presumptions in some countries, however, as enforcement officials and the courts gain experience and sophistication in competition analysis.' 


\subsubsection{Assessment}

Above we saw that presumptions can fulfil their economic function of reducing social costs only if it is highly probable that the presumed situation is true. So we have to ask if it is highly probable that a dominant position exists if the market share is $30 \%, 40 \%$ or $50 \%$. The assumption of such a simplistic correlation has met with scepticism. The existence of dominance has to be based on many indicators of which market share is only one. ${ }^{75}$ So whether the threshold is set at $30 \%$ or $50 \%$ is not the question. The concept of 'contestable markets' has shown that even a monopoly may be a competitive market if barriers to entry are low or nonexistent. ${ }^{76}$ If there are no barriers to entry and no sunk costs, the incumbent is under pressure from potential competitors who might access the market on short notice if he charges monopoly prices.

Accordingly, scepticism about the adequacy of market share-based presumptions is widespread and the importance of other factors for conferring independent power has been stressed. ${ }^{77}$ The discussion in Germany about the legal status of these presumptions is revealing. Although the law expressly states that an undertaking is presumed to be dominant if it has a market share of at least forty per cent (Art. 18 (4) ARC), there is an ongoing debate whether this is a regular presumption, prima facie evidence or a way to impose a secondary burden of proof. ${ }^{78}$ As an intermediary result, we may note that it is far from clear that the reduction of administrative costs due to the presumption of dominance will exceed the additional error costs.

75 See J. Vickers, 'Some Economics of Abuse of Dominance', University of Oxford, Department of Economics - Discussion Paper Series no. 376 (2007), www.economics.ox.ac.uk/Research/wp/pdf/paper376.pdf, 2007, p. 4: 'High shares alone never imply dominance.'

W. Baumol, J. Panzar and R. Willig, Contestable Markets and the Theory of Industry Structure (Harcourt Brace Jovanovich 1982).

77 See A. Fuchs and W. Möschel, in Immenga \& Mestmäcker (eds.), Wettbewerbsrecht Band 1, EU/Teil 2, Kommentar zum Europäischen Kartellrecht (C.H. Beck, 5th ed. 2012), Art. 102 AEUV para. 73 et seq.

78 A recent study concludes that the significance of these presumptions for private enforcement is not conclusively resolved. See J. P. Westhoff (supra note 2), p. 90. For a position in favour of the full effect of presumption, see P. Pohlmann, 'Die Marktbeherrschungsvermutungen des GWB im Zivilprozess', 164 Zeitschrift für das gesamte Handelsrecht und Wirtschaftsrecht (2000), 589, p. 596 et seq. 


\subsection{Predatory Pricing}

\subsubsection{Sales Below Cost}

Under which conditions should low selling prices be qualified as abusive? According to German law, exclusionary conduct exists if an undertaking with superior market power sells below cost (Art. 20 (3) ARC).$^{79}$ In the AKZO case, the European Court of Justice has held that prices below average variable costs must be regarded as abusive. The same is true for prices below average total costs, but above average variable costs if they are determined as part of a plan for eliminating a competitor. ${ }^{80}$ In its Enforcement Priorities with respect to Art. 102 TFEU, the European Commission has adopted a modernized version of these rules. The central question is whether pricing is capable of foreclosing efficient competitors from the market. ${ }^{81}$

\subsubsection{Assessment}

The rules of the Court of Justice and the European Commission start from the idea that it is highly probable that sales below cost constitute an abuse pursuant to Art. 102 TFEU. This assumption has been criticized. According to Martin Hellwig, the assertions of the European Court of Justice in the $A K Z O$ case are wrong, at least in the general way as they have been made by the court. For example, it may make economic sense to sell below average variable costs in the case of introductory prices or of cross-subsidizing in multi-product firms. ${ }^{82}$

Even if we take into account that it is generally accepted that the dominant firm may invoke an objective justification (for which it has to provide the necessary evidence $^{83}$ ), it is again not clear if savings in administrative costs are higher than the increase of error costs due to a (perhaps overly inclusive) rule.

\footnotetext{
79 For the prima facie rule in Art. 20 (4) ARC, see supra note 42.

80 Case C-62/86 AKZO/Commission [1991] ECR I-3359, para 71-72.

81 European Commission, Guidance on the Commission's enforcement priorities in applying Article 82 of the EC Treaty to abusive exclusionary conduct by dominant undertakings, OJ 2009, C 45/7, para. 63 et seq. The average variable costs are replaced by the average avoidable costs (AAC), the average total costs by the long-run average incremental costs (LRAIC).

82 M. Hellwig, Wirtschaftspolitik als Rechtsanwendung - Zum Verhältnis von Jurisprudenz und Ökonomie in der Wettbewerbspolitik (Forschungsgemeinschaft für Nationalökonomie an der Univ. St. Gallen, 2007), p. 6 et seq.

83 Enforcement Priorities (supra note 81), para. 31.
} 


\subsection{Passing on}

\subsubsection{Passive and Active Use}

One of the most intricate questions in the context of private enforcement of competition law is the problem of 'passing on'. Can the respondent defend himself against a damage claim with the argument that the claimant has shifted the cartel overcharge onto the next market level? ${ }^{84}$ In German law (Art. 33 (3) 2 ARC) the following rule is to be found: "If a good or service is purchased at an excessive price, a damage shall not be excluded on account of the resale of the good or service.' This rule is not conceived as a presumption but as a rule on the calculation of damages, i.e. on the mitigation of damages by benefits received. This rule has an effect on the onus probandi, however: mitigation of damages has to be proven by the party pleading this argument, i.e. by the infringer. In other countries, this distribution of the burden of proof can be deduced from the general rules (if the passing on defence is recognized).

The European Commission has gone one step further by suggesting a presumption for the active use of the passing-on argument in the White Paper on damages actions: 'Indirect purchasers should be able to rely on the rebuttable presumption that the illegal overcharge was passed on to them in its entirety. ${ }^{85}$ But as perpetrators bear the burden of proof for the passive use of the passing on defence, a non liquet would burden them twice, first in damages claims from direct purchasers where they could not prove the passing-on defence, and second in damages claims of lower commercial levels, where they could not rebut the presumption for the active use of passing on. ${ }^{86}$

\subsubsection{Assessment}

Here again, we have to ask the question if it is highly probable that the overcharge has been passed on to the next market level. This depends on many circumstances, such as the degree of competition on downstream markets as well as on the price

See the study of F. W. Bulst, Schadensersatzansprüche der Marktgegenseite im Kartellrecht (Nomos 2006). For the context of Art. 102 TFEU, see M. O. Mackenrodt, 'Private Incentive, Optimal Deterrence and Damage Claims for Abuses of Dominant Positions', in Mackenrodt, Conde Gallego \& Enchelmaier (eds.), Abuse of Dominant Position: New Interpretation, New Enforcement Mechanisms? (Springer 2008), p. 174 et seqq.

European Commission, White Paper (supra note 1), p. 8. But see now the balanced rule in Art. 13 of the Commission Proposal for a Directive of the European Parliament and of the Council on Certain Rules Governing Actions for Damages under National Law for Infringements of the Competition Law Provisions of the Member States and of the European Union, COM(2013) 404 final.

86 See the critique of J. Bornkamm, 'Cui malo? Wem schaden Kartelle?', Gewerblicher Rechtsschutz und Urheberrecht 2010, 501, p. 504-505. 
elasticity of demand. ${ }^{87}$ Error costs appear to be particularly high if presumptions do not only influence the outcome of a case between two parties, but also asymmetrically favour the claims of indirect purchasers, thus creating the risk of multiple liability.

\section{Conclusions}

The topic of presumptions touches the foundations of competition law. Whereas US antitrust law was based from the start on the prohibition principle, in Europe the abuse model initially prevailed. Under the abuse principle, the anticompetitive conduct is identified, but not prohibited. In abuse systems, competition law rules may be qualified as presumptions for the government to intervene. ${ }^{88} \mathrm{With}$ the transition to the prohibition principle, presumptions have received a more specific task. Within a competition law rule, they alleviate evidentiary burden with respect to single elements of that rule.

\subsection{Insights}

Presumptions deploy full effect in private law. ${ }^{89}$ By shifting the burden of proof to the other party, presumptions ease difficulties of providing evidence. In administrative procedure, their consequences are tempered by the inquisitorial system. In the field of criminal law, the presumption of innocence applies, albeit with qualifications in the field of administrative offences. At least with respect to the three examples considered here, the economic rationale of presumptions seems to be rather weak.

\subsection{The Link Between Presumptions and Disclosure Rules}

Yet an overall assessment has to take into account the contribution of presumptions to private enforcement in general. Their function is to cure the problem of access to evidence virulent in continental legal systems (without comprehensive systems of disclosure). Their evaluation has to be made in this context. Presumptions and the rules on access to evidence are communicating vessels: presumptions may compensate difficulties in accessing evidence, and better access to evidence may render presumptions dispensable.

The preceding remarks suggest the following conjecture: The fact that presumptions have found their way into the law and into court practice, although the economic rationale of many of these presumptions is weak, proves their urgent

See F. W. Bulst (supra note 84), p. 281 et seq.

See D. Gerber (supra note 38), p. 49.

But also see the discussion on the status of the presumptions of dominance in German law, supra note 78 . 
need at least if the rules on access to evidence tend to be restrictive. Hence, in an evolutionary sense, these presumptions attest to the existence of a special information asymmetry in competition law. Apparently, the one-size-fits-all approach for evidence access is counterbalanced by the emergence of rules on the distribution of proof.

\subsection{Preference for Improved Disclosure or for Presumptions?}

This raises the question if preference should be given to better access to evidence or to presumptions. Rolf Stürner has clearly opted for the former option: 'When aiming at redressing asymmetries, shifting or lowering the burden of proof should be considered a worse solution compared with a well working system of procedural obligations to disclose and cooperate. ${ }^{90}$ This is even truer when the probability of the presumption's veracity is not very high.

On the other hand, presumptions have the advantage of focusing on specific aspects, whereas disclosure obligations are more general and regularly raise the problem of what is to be disclosed. There is the danger of 'underdisclosure' and 'overdisclosure': either too little is given so that the claimant is not able to discharge his burden of proof, or too much is given so that the other party has difficulties in finding what is relevant for his case. Presumptions avoid this problem: the party burdened by the presumption will have an interest to produce exactly the evidence pertinent for the question. Moreover, in most cases, presumptions focus on a certain aspect that very often may be better elucidated by the party burdened by the presumption.

In sum, disclosure obligations and presumptions have their pros and cons. The requirements of disclosure rules have to be high if an excessive litigation culture is to be avoided. This is why the proposals of the European Commission in the White Paper - restricting disclosure obligations to precise categories of evidence seem promising. It is the task of the courts to submit disclosure obligations for a strict control of proportionality. Yet if the plaintiff cannot determine 'certain categories' of evidence he will not be able to discharge the burden of proof. Presumptions may fix this shortcoming: they are more targeted with respect to certain questions, and they create incentives to produce exactly the evidence needed for the assessment of certain questions. In this way some problems linked to disclosure obligations (plausibility or sufficient probability of an infringement, nemo tenetur, protection of business secrets) can also be avoided.

$90 \quad$ See R. Stürner in Basedow (supra note 26), p. 184. 


\subsection{Outlook}

Therefore, in our view, a combination of carefully shaped disclosure rules and presumptions is the best option. Whereas presumptions are less important in public enforcement, they are essential for private law, especially if disclosure obligations are restrictive (or do not exist at all). The economic approach of competition law has amplified the need for an appropriate mix of disclosure and presumptions. ${ }^{91}$ But an effects-based analysis is costly and will often require the production of economic expertise..$^{22}$ Administrative costs may be reduced if the burden of proof is shifted to the respondent. If presumptions are restricted to facts that the respondent is better placed to produce, the social costs will also be reduced. Hence, it is essential to look at the problem of evidence in a holistic way without isolating single elements. In particular, presumptions have to be assessed with the rules on evidence access in mind. Since these rules are constantly changing, assessments may vary over time.

91 See D. Gerber (supra note 38), p. 310-312 with respect to the consequences on the global level.

92 See R. A. Heizmann and R. Zäch, 'Expertisekosten als neue Hürden für Kartellklagen', in Leupold, Rüetschi, Stauber \& Vetter (eds.), Der Weg zum Recht - Festschrift für Alfred Bühler (Schulthess 2008), p. 3 et seq. 